\title{
Social Networks, Interpersonal Trust, and Support for Democracy in East Asia
}

\author{
Ching-Hsing Wang ${ }^{1}$ \\ ${ }^{1}$ Hobby Center for Public Policy, University of Houston, Texas, USA \\ Correspondence: Ching-Hsing Wang, Hobby Center for Public Policy, University of Houston, Texas, USA
}

Received: December 23, 2014

Accepted: January 9, 2015

Available online: January 27, 2015

doi:10.11114/ijsss.v3i2.650

URL: http://dx.doi.org/10.11114/ijsss.v3i2.650

\begin{abstract}
Civil society has been regard as a prerequisite for democracy, and social networks and interpersonal trust are two important elements of civil society. By using data from the Asian Barometer Survey, this study investigates the effects of social networks and interpersonal trust on public support for democracy in three East Asian democracies - Japan, South Korea, and Taiwan. The results of statistical analysis show that social networks, rather than interpersonal trust, exert significant positive effects on public support for democracy in Japan and Taiwan. By contrast, it is interpersonal trust to affect public support for democracy in South Korea. Nonetheless, it should also be noted that trust in political institutions, democratic values, and education far outweigh social networks and interpersonal trust to impact public support for democracy in these East Asian democracies.
\end{abstract}

Keywords: social networks, interpersonal trust, support for democracy, civil society, Asian Barometer, East Asia.

\section{Introduction}

Civil society has been regard as an essential condition for successful democratization. Putnam and his colleagues (1993) investigated the civic traditions in modern Italy and found a strong link between the performance of political institutions and the character of civic life - what he termed "the civic community." Such communities are characterized by civic engagement, political equality, solidarity, trust and tolerance and a strong associational life. They concluded that democracies work better when there exists an independent and long-standing tradition of civic engagement. Following his work on civic involvement in Italy, Putnam (1995) explored social connections and civic engagement in America and found that America's social capital was in decline. He concluded that "The concept of 'civil society' has played a central role in the recent global debate about the preconditions for democracy and democratization (Putnam, 1995: 77)." Although some of the major proponents of civil society suggest that the relationship between civil society and democracy is one of correlation, not causation (Schmitter, 1997), some previous studies have confirmed the important role of civil society in helping the consolidation of democracy (Linz \& Stepan, 2001). As a result, we can anticipate that people living in a high level of civil society should be more likely to support democracy.

However, although Putnam pointed out the important characteristics of civil society, the concept of civil society is difficult to be operationalized for empirically minded social scientists. There is not much agreement on the indicators of civil society and therefore, the measurement of civil society has been debated. To acknowledge the difficulty in the measurement of civil society, this study follows Gibson's approach to focus on two key attributes of civil society social networks and interpersonal trust, and examines their effects on public support for democracy. Gibson (2001) thought that social networks are important means for the diffusion of democratic ideas and that interpersonal trust makes cooperation (political, economic, and social) possible, mitigating collective action dilemmas.

Being different from Gibson's work, this study focuses on three democratic countries in East Asia - Japan, South Korea, and Taiwan, mainly due to the lack of systematic analysis of the relationship between civil society and public support for democracy in East Asia. Moreover, these three countries are similar in many respects. First, in culture, Japan, South Korea, and Taiwan are deeply influenced by Confucian traditions so that their cultural backgrounds are analogous to each other to some extent (Inglehart \& Welzel, 2005). Second, in economics, Japan, South Korea, and Taiwan have better economic development and they constitute Asia's most advanced market economies. Therefore, the economic difference among these three countries can be controlled. Finally, in politics, Japan, South Korea, and Taiwan are stable democracies and have the same levels of political rights and civil liberties according to Freedom House's evaluations 
(see Freedom House: https://www.freedomhouse.org/). The main difference among them might be relatively short experiences in democratic practices in South Korea and Taiwan in comparison with Japan. As a consequence, these similarities in cultural, economic, and political contexts enable the inclusion of these three countries in the analysis possible.

Overall, this study aims to investigate the effects of social networks and interpersonal trust on public support for democracy in East Asian democracies. The remainder of this study is organized as follows. The next section briefly reviews the literature on the relationships between social networks, interpersonal trust and democracy. The third section introduces the data used for empirical analysis, measurement of variables as well as model specification. The fourth section presents the empirical results. Finally, the conclusion section summarizes the key findings of this study and provides some implications for future study.

\section{Social Networks, Interpersonal Trust and Democracy}

Although the concept of civil society is rather ambiguous and may mean different things to different people, students of democratization have achieved a consensus that civil society is a prerequisite for democracy. However, when it comes to empirical examination of the effect of civil society on democratization, scholars have different opinions on how to constitute effective indicators of civil society. As mentioned above, due to the difficulty in measurement of civil society, this study follows Gibson's approach to use social networks and interpersonal trust as indicators of civil society and examines their relationships with public support for democracy.

First of all, with regard to the relationship between social networks and democracy, Putnam (1993) argued that civil associations contribute to the effectiveness and stability of democratic government, because associations can instill in their members habits of cooperation, solidarity, and public-spiritedness. Moreover, members of associations display more political sophistication, social trust, political participation, and subjective civic competence, all of which are conducive to the operation of democracy. Besides, some previous studies have indicated the close relationship between social networks and social capital. For example, La Due Lake and Huckfeldt (1998) found that social capital is a function of the political expertise within an individual's network of relations, the frequency of political interaction within the network, and the size or extensiveness of the network. Furthermore, social capital is regarded as an important factor to affect the operation of democracy. As a result, based upon the above discussion, it is expected to observe a positive relationship between social networks and public support for democracy. Gibson's study (2001) confirms such relationship, finding that in Russia, those embedded in extensive social networks are more likely to support democratic institutions and processes.

Second, in terms of the relationship between interpersonal trust and democracy, interpersonal trust is regarded to be able to sustain a cooperative social climate, to facilitate collective behavior, and to encourage a concern for the public interest. Moreover, interpersonal trust makes it easier, less risky and more rewarding for citizens to participate in community and civic affairs, and helps to build the social institutions of civil society upon which stable and efficient democracy depends. Past studies confirm the close relationship between interpersonal trust and democracy. For instance, Newton (2001) found that by and large there is a general tendency for countries with higher levels of interpersonal trust (he called social trust) to show higher levels of political confidence, and vice versa; Zmerli and Newton (2008) found the significant correlations between interpersonal trust (they also called social trust) and satisfaction with democracy. Nevertheless, it is notable that interpersonal trust has a much stronger link with confidence in political institutions than with satisfaction with democracy. Based upon the above-mentioned studies, it is reasonable to expect a positive relationship between interpersonal trust and democracy, but some studies on post-communist countries find no significant relationship between them. Like Gibson, Mishler and Rose (2005) examined the political consequence of trust in Russia and found that interpersonal trust has no appreciable effects, direct or indirect, on any of the democratic attributes. To synthesize their finding and Gibson's finding, it seems that interpersonal trust plays a limited role in affecting public support for democracy in post-communist countries.

Although previous studies have discussed the relationship between civil society and democracy in Asia, they either lack of empirical analysis (Bunbongkarn, 2004) or only focus on specific country (Albritton \& Bureekul, 2002). Due to lack of study on systematic comparison of Asian countries in terms of the relationship between civil society and democracy, this study is expected to provide a preliminary analysis for future study. To sum up, this study employs social networks and interpersonal trust to operationalize civil society and examines the effects of social networks and interpersonal trust on public support for democracy in Japan, South Korea, and Taiwan. Specifically, this study tests the following two hypotheses:

Hypothesis 1: Social networks has a positive effect on support for democracy. That is, people with more extensive social networks are more likely to support democracy.

Hypothesis 2: Interpersonal trust has a positive effect on support for democracy. That is, people with higher levels of 
interpersonal trust are more likely to support democracy.

\section{Data, Measurement, and Model Specification}

This study utilizes the data from the Asian Barometer Survey, which is a program under the auspice of the University Academic Excellence Development Projects funded by Taiwan Ministry of Education. This project is the largest, most careful and systematic comparative survey of attitudes and values toward politics, power, reform, democracy and citizens' political actions in Asia and led by Taiwan scholars. The Asian Barometer Survey has released three waves of survey data and this study uses the second wave of survey data that were collect respectively from 2005 to 2008 mainly because it contains survey questions required for this study. Although the second wave of Asian Barometer Survey covers thirteen Asian political systems, this study simply focuses on three East Asian democracies: Japan, South Korea, and Taiwan. Given that the data were collected by the international cooperation research team and the survey in each country was conducted on the basis of the same standard questionnaire, the wording of survey questions is basically identical, which makes this study be able to compare these three countries more easily and compatibly without worrying about the problem of measurement error, although translation of questionnaires might be a problem. The following describes the measurement of variables (for detailed question wording, please see the Appendix).

Support for democracy: The dependent variable in this study is whether people support democracy and I base my analysis on a survey item that is widely used to gauge popular support for democracy as a preferred political system. Typically, the respondents are asked to choose among three statements: (1) Democracy is always preferable to any other kind of government; (2) Under some circumstances, an authoritarian government can be preferable to a democratic one; and (3) For people like me, it does not matter whether we have a democratic or a nondemocratic regime. This has been the most widely used item due not only to its face validity, but also to the way in which it facilitates meaningful comparison (Chu, Bratton, Lagos, Shastri, \& Tessler, 2008). Similar to previous research, this study codes the respondents' answers to this survey question as 1 for those who think of democracy as the best political system all the time and 0 otherwise.

Social networks: In this study, two variables are used to measure social networks and both of them focus on the frequency of respondents' interaction with other people. The first variable is the number of groups in which respondents participate. This study assumes that if people take part in more formal groups, they will have more opportunities to get information about public affairs, and talk about politics with other people. By the same token, if people contact more people in their daily life, they will also have more chances to learn about politics and public affairs. Therefore, the second variable to measure social network is the number of people whom respondents contact per day. The measurement of both variables implies that when people participate in more groups and contact more people, their levels of social integration will become higher, which is conducive to the emergence of civil society. Both the number of group in which respondents participate and the number of people whom respondents contact per day are treated as continuous variables. The former is coded to range from 0 to 3 , because the respondents are only allowed to provide the names of three groups they belong to at most; the latter is coded to range from 1 to 5 , because the respondents' answers are classified into five categories and a higher values means more people the respondents contact in a typical week day.

Interpersonal trust: This study uses three survey questions to measure interpersonal trust. One of them asks to what extent that respondents trust people in general and the other two questions inquire respondents about their trust in specific people: their relatives and the people with whom they interact. Trust in people in general is coded as 1 for those who think that people can be trusted and 0 otherwise, because the respondents are only given two response options "most people can be trusted" and "you must be very careful in dealing with people." By contrast, the respondents express trust in their relatives and the people with whom they interact on a four-point scale, so this study treats these two kinds of trust as continuous variables and codes them to range from 0 to 3 . A higher value means that respondents trust their relatives and the people with whom they interact more.

Control Variables: To ensure that the effects of social networks and interpersonal trust on public support for democracy are not spurious, several variables are included as control variables. First of all, some studies have found the close relationship between institutions and democracy (Huntington, 1968; Anderson \& Guillory, 1997; O'Donnell, 1998), and Chu et al. (2008) found that the levels of trust that people feel toward parliament, parties, and courts have an influence on people's attitude toward democracy. As a result, it is necessary to control the effect of people's trust in political institutions when it comes to support for democracy. In Asian Barometer, the respondents are asked to express their trust in nine political institutions on a four-point scale and thus, this study uses the average score of the respondents' trust in these political institutions to measure trust in political institutions. The value range of trust in political institutions is between 0 and 3. Second, individuals' democratic values also have an important influence on their support for democracy and it is expected that people with higher levels of democratic values are more likely to support democracy. The Asian Barometer Survey provides a battery of questions to measure democratic values which totally 
include nine questions, and the respondents answer these questions on a four-point scale. Therefore, this study recodes the respondents' answers to range from 0 to 3 and then takes average of the respondents' answers to these nine questions to constitute the index of democratic values. The value range of the index of democratic values is between 0.33 and 3. The higher value means that the respondents have higher levels of democratic values. This study anticipates a positive relationship between democratic values and support for democracy. Finally, to control possible effects of demographic variables, this study uses a dummy variable to measure respondents' educational level, and codes it as 1 for those who have the educational level of college and above degree, and 0 otherwise. In other words, those with educational level of senior high school and below degree are treated as the reference group. Furthermore, one dummy variable is coded as 1 if the respondent is female and 0 otherwise and the respondents' age is measured by the number of years since birth. Table 1 reports the descriptive statistics of all variables.

Table 1. Descriptive Statistics of Variables

\begin{tabular}{|c|c|c|c|c|c|}
\hline Country & Variable & Mean & S.D. & Min. & Max. \\
\hline \multirow{11}{*}{ Japan } & Support for democracy & 0.70 & 0.46 & 0 & 1 \\
\hline & Number of groups the respondent participates in & 1.46 & 1.11 & 0 & 3 \\
\hline & Number of people the respondent contacts per day & 2.42 & 1.15 & 1 & 5 \\
\hline & Trust in people in general & 0.35 & 0.48 & 0 & 1 \\
\hline & Trust in relatives & 2.30 & 0.65 & 0 & 3 \\
\hline & Trust in people the respondent interacts with & 1.92 & 0.59 & 0 & 3 \\
\hline & Trust in political institutions & 1.24 & 0.45 & 0 & 3 \\
\hline & Democratic values & 1.89 & 0.43 & 0.33 & 3 \\
\hline & College and above degree & 0.52 & 0.50 & 0 & 1 \\
\hline & Female & 0.45 & 0.50 & 0 & 1 \\
\hline & Age & 46.56 & 16.16 & 20 & 91 \\
\hline \multirow{11}{*}{ South Korea } & Support for democracy & 0.48 & 0.50 & 0 & 1 \\
\hline & Number of groups the respondent participates in & 0.40 & 0.81 & 0 & 3 \\
\hline & Number of people the respondent contacts per day & 2.72 & 1.19 & 1 & 5 \\
\hline & Trust in people in general & 0.32 & 0.47 & 0 & 1 \\
\hline & Trust in relatives & 2.16 & 0.62 & 0 & 3 \\
\hline & Trust in people the respondent interacts with & 1.45 & 0.68 & 0 & 3 \\
\hline & Trust in political institutions & 1.03 & 0.46 & 0 & 3 \\
\hline & Democratic values & 1.72 & 0.34 & 0.56 & 3 \\
\hline & College and above degree & 0.41 & 0.49 & 0 & 1 \\
\hline & Female & 0.48 & 0.50 & 0 & 1 \\
\hline & Age & 41.49 & 14.00 & 19 & 80 \\
\hline \multirow{11}{*}{ Taiwan } & Support for democracy & 0.51 & 0.50 & 0 & 1 \\
\hline & Number of groups the respondent participates in & 0.38 & 0.70 & 0 & 3 \\
\hline & Number of people the respondent contacts per day & 2.70 & 1.14 & 1 & 5 \\
\hline & Trust in people in general & 0.37 & 0.48 & 0 & 1 \\
\hline & Trust in relatives & 2.11 & 0.62 & 0 & 3 \\
\hline & Trust in people the respondent interacts with & 1.85 & 0.60 & 0 & 3 \\
\hline & Trust in political institutions & 1.31 & 0.46 & 0 & 3 \\
\hline & Democratic values & 1.68 & 0.32 & 0.33 & 3 \\
\hline & College and above degree & 0.30 & 0.46 & 0 & 1 \\
\hline & Female & 0.43 & 0.50 & 0 & 1 \\
\hline & Age & 39.82 & 14.25 & 21 & 94 \\
\hline
\end{tabular}

Note: The number of observations for Japan is 673; the number of observations for South Korea is 782; and the number of observations for Taiwan is 1018.

With regard to model specification, since the dependent variable in this study is dichotomous, I employ the binary logistic regression model to estimate the effects of social networks and interpersonal trust on public support for democracy in East Asian democracies. Specifically, binary logistic regression model takes the form of

$$
\ln \Omega(X)=\ln \left(\frac{P}{1-P}\right)=a+b X
$$

where $\ln \Omega(X)$ is the natural logarithm of the conditional odds of voting relative to non-voting; $X$ is a vector of independent variables, $\boldsymbol{b}$ is a vector of regression estimates and $\boldsymbol{a}$ is a constant of regression estimates. For this study, the statistical model can be presented as the following equation:

Support for democracy $=\beta_{0}+\beta_{1}$ (Number of groups the respondent participates in) $+\beta_{2}$ (Number of people the 
respondent contacts per day) $+\beta_{3}$ (Trust in people in general) $+\beta_{4}$ (Trust in relatives) $+\beta_{5}$ (Trust in people the respondent interacts with) $+C_{i} X_{i}$

where $\beta_{0}$ is the constant, $\beta_{1}$ through $\beta_{5}$ are the coefficients of interest for this study, $X_{i}$ is a vector of control variables, and $C_{i}$ is a vector of coefficients for control variables. In particular, I estimate two different models to assess the effects of social networks and interpersonal trust on support for democracy in the following section - one model without control variables and the other one with the controls.

\section{Empirical Results}

The first step of my analysis is to examine whether there are significant differences in social networks and interpersonal trust among Japan, South Korea, and Taiwan. Tables 2 and 3 present the results of ANOVA with regard to two variables of social networks, whereas Tables 4 through 6 repots the results of ANOVA for three variables of interpersonal trust. First of all, Table 2 shows that there are significant differences in the number of groups in which the respondents participate among Japan, South Korea, and Taiwan. Specifically, more than 70 percent of people in South Korea and Taiwan do not participate in any group. On the contrary, only approximately 27 percent of people in Japan are not members of any group. Furthermore, more than 47 percent of people participate in more than two groups in Japan. The difference in the number of group in which people participate among these three countries is statistically significant at the 0.001 level and it is obvious that people in Japan participate in more groups than people both in South Korea and Taiwan.

Table 2. ANOVA of Number of Groups in which the Respondent Participates

\begin{tabular}{lcccccc}
\hline & \multicolumn{5}{c}{ Number of group you participate in } & ANOVA \\
\hline Japan & 0 & 1 & 2 & 3 & Total \# & $F=353.98$ \\
South Korea & $26.6 \%$ & $27.0 \%$ & $23.5 \%$ & $23.9 \%$ & 673 & d.f. $=(2,2423)$ \\
Taiwan & $75.7 \%$ & $12.9 \%$ & $6.6 \%$ & $4.8 \%$ & 782 & $p<0.001$ \\
\hline
\end{tabular}

Note: $F: F$-statistic; $d . f:$ Degree of freedom; $p: p$-value.

Second, Table 3 presents that there are also significant differences in number of people whom the respondent contact per day among Japan, South Korea, and Taiwan. In particularly, more than 50 percent of people in all three countries contact less than 20 people per day. Slightly more than 30 percent of people in Japan and South Korea contact 5 to 9 people per day, whereas a similar percentage of Taiwanese people contact 10 to 19 people per day. Although the difference in the number of people with whom respondents contact per day among three countries is not large as the difference in the number of group in which respondents participate, the difference still achieves statistical significance at the 0.001 level.

Table 3. ANOVA of Number of People Whom the Respondent Contacts Per Day

\begin{tabular}{lccccccc}
\hline & \multicolumn{4}{c}{ Number of people you contact per week } & \multicolumn{2}{c}{ ANOVA } \\
\hline Japan & $0-4$ & $5-9$ & $10-19$ & $20-49$ & 50 or more & Total \# & $F=17.73$ \\
South Korea & $24.9 \%$ & $31.3 \%$ & $25.6 \%$ & $13.1 \%$ & $5.1 \%$ & 673 & A \\
Taiwan & $16.3 \%$ & $31.2 \%$ & $25.5 \%$ & $18.3 \%$ & $8.7 \%$ & 782 & $d .2423)$ \\
\hline
\end{tabular}

Note: $F$ : $F$-statistic; $d$.f.: Degree of freedom; $p: p$-value.

Third, in terms of trust in people in general, Table 4 shows that generally speaking, most people in these three countries express distrust in people. In all three countries, more than 60 percent of respondents think that it must be very careful to deal with people. Particularly, approximately 68 percent of people in South Korea do not trust people in general. It seems that in East Asia, interpersonal relationship is difficult to be built on trust. Moreover, the difference in trust in people in general among these three countries is not statistically significant (i.e., $p$-value is greater than 0.05), which means that there is no significant difference in trust in people in general among Japan, South Korea and Taiwan.

Table 4. ANOVA of Trust in People in General

\begin{tabular}{lcccc}
\hline & \multicolumn{3}{c}{ Trust in people in general } & \multirow{2}{*}{ ANOVA } \\
\cline { 2 - 4 } & $\begin{array}{c}\text { You must be very careful } \\
\text { in dealing with people }\end{array}$ & $\begin{array}{c}\text { Most people can } \\
\text { be trusted }\end{array}$ & Total \# & \\
\hline Japan & $64.9 \%$ & $35.1 \%$ & 673 & $F=1.54$ \\
South Korea & $67.9 \%$ & $32.1 \%$ & 782 & d.f. $=(2,2423)$ \\
Taiwan & $63.1 \%$ & $36.9 \%$ & 1018 & $p>0.05$ \\
\hline
\end{tabular}

Note: $F: F$-statistic; $d . f:$ Degree of freedom; $p: p$-value. 
On the contrary, when asked trust in familiar people, people in these three countries express different attitude toward interpersonal trust. Table 5 presents that most people in these three countries trust their relatives. Specifically, more than 90 percent of people in Japan express trust in their relatives, whereas the percentages of trust in relatives in South Korea and Taiwan are slightly lower than that in Japan (i.e., 88.3 percent and 86.7 percent respectively). Furthermore, nearly 40 percent of Japanese people exhibit a great deal of trust in their relatives, which is higher than people in South Korea and Taiwan (i.e., 27.9 percent and 24.4 percent respectively). The difference in trust in relatives among these three countries is statistically significant at the 0.001 level, which implies that there is a significant difference in trust in relatives among Japan, South Korea, and Taiwan.

Table 5. ANOVA of Trust in Relatives

\begin{tabular}{lcccccc}
\hline & \multicolumn{5}{c}{ Trust in relatives } & \\
\cline { 2 - 5 } & None at all & $\begin{array}{c}\text { Not very much } \\
\text { trust }\end{array}$ & $\begin{array}{c}\text { Quite a lot of } \\
\text { trust }\end{array}$ & $\begin{array}{c}\text { A great deal of } \\
\text { trust }\end{array}$ & Total \# & ANOVA \\
\hline Japan & $0.6 \%$ & $9.1 \%$ & $50.4 \%$ & $39.9 \%$ & 673 & $F=14.69$ \\
South Korea & $0.5 \%$ & $11.2 \%$ & $60.4 \%$ & $27.9 \%$ & 782 & $d . f .=(2,2423)$ \\
Taiwan & $0.6 \%$ & $12.7 \%$ & $62.3 \%$ & $24.4 \%$ & 1018 & $p<0.001$ \\
\hline
\end{tabular}

Note: $F: F$-statistic; $d . f:$ : Degree of freedom; $p: p$-value.

Finally, in terms of trust in other people with whom people interact, people in Japan still display a much higher level of trust. About 80 percent of people in Japan say that they trust people with whom they interact. Most people in Taiwan also express trust in people with whom they interact. Nevertheless, more than 50 percent of people in South Korea do not trust people with whom they interact. Besides, the result of ANOVA reports that the difference in trust in other people with whom people interact among these three countries is statistically significant at the 0.001 level. That is, there is a significant difference in trust in other people with whom people interact among Japan, South Korea and Taiwan.

Table 6. ANOVA of Trust in People with Whom the Respondent Interacts

\begin{tabular}{lcccccc}
\hline & \multicolumn{2}{c}{ Trust in people you interact with } & ANOVA \\
\cline { 2 - 5 } & None at all & $\begin{array}{c}\text { Not very much } \\
\text { trust }\end{array}$ & Quite a lot of trust & $\begin{array}{c}\text { A great deal of } \\
\text { trust }\end{array}$ & Total \# & AN \\
\hline Japan & $0.6 \%$ & $20.0 \%$ & $66.6 \%$ & $12.8 \%$ & 673 & d.f. $=(2,2423)$ \\
South Korea & $6.0 \%$ & $47.3 \%$ & $42.1 \%$ & $4.6 \%$ & 782 & $p<0.001$ \\
Taiwan & $1.0 \%$ & $23.4 \%$ & $65.2 \%$ & $10.4 \%$ & 1018 & $p$ \\
\hline
\end{tabular}

Note: $F: F$-statistic; d.f.: Degree of freedom; $p: p$-value.

Based upon the above findings, it is concluded that there is a significant difference in social networks among Japan, South Korea and Taiwan, and it seems that people in Japan have more extensive social networks than people both in South Korea and Taiwan. Besides, with regard to interpersonal trust, people in all three countries express distrust in people overall. Nevertheless, when it comes to familiar people, people in Japan and Taiwan express trust in them. By contrast, people in South Korea only express higher levels of trust in their relatives and more than half of them distrust people with whom they interact, which implies that people in South Korea only trust their family members and keep vigilance against other people. As a result, the result suggests that people in Japan and Taiwan have higher levels of interpersonal trust than their counterparts in South Korea.

After knowing the significant differences in social networks and interpersonal trust among Japan, South Korea and Taiwan, the next step of my analysis is to investigate the impacts of social networks and interpersonal trust on public support for democracy. Table 7 reports the results of simple model which only includes the key independent variables. It is noticed that most variables do not achieve conventional statistical significance. Only number of groups in which people participate has a significant effect on public support for democracy in Japan and Taiwan and trust in people in general significantly affects public support for democracy in South Korea. Specifically, in Japan, a one unit increase in number of groups in which the respondents take part is associated with the increase in the odds of support for democracy by a factor of 1.313, all else being equal. Moreover, if Japanese people participate in three groups, the probability of their support for democracy will increase by 5.6 percent. In addition, in Taiwan, a one unit increase in number of groups in which the respondent participate is associated with the increase in the odds of support for democracy by a factor of 1.256 and if people participate in three groups, the probability of their support for democracy will also increase by 5.6 percent. Hence, it is known that the maximum effect of number of groups in which people take part on public support for democracy is about the same in Japan and Taiwan. On the other hand, in terms of South Korea, if people express trust in people overall, the probability of their support for democracy will increase by 11.1 percent. The results of preliminary analysis of simple model imply that social networks play a pivotal role in affecting 
public support for democracy in Japan and Taiwan; by contrast, it is interpersonal trust to influence public support for democracy in South Korea.

Table 7. Binary Logistic Analysis of Support for Democracy - Simple Model

\begin{tabular}{|c|c|c|c|c|c|c|}
\hline & \multicolumn{2}{|c|}{ Japan } & \multicolumn{2}{|c|}{ South Korea } & \multicolumn{2}{|c|}{ Taiwan } \\
\hline & $\begin{array}{l}\text { Coef. } \\
\text { (S.E.) }\end{array}$ & $\begin{array}{c}\text { O.R. } \\
\text { (M.E.) } \\
\end{array}$ & $\begin{array}{l}\text { Coef. } \\
\text { (S.E.) }\end{array}$ & $\begin{array}{c}\text { O.R. } \\
\text { (M.E.) }\end{array}$ & $\begin{array}{l}\text { Coef. } \\
\text { (S.E.) }\end{array}$ & $\begin{array}{c}\text { O.R. } \\
\text { (M.E.) }\end{array}$ \\
\hline \multirow{4}{*}{$\begin{array}{l}\text { Number of groups the } \\
\text { respondent participates in } \\
\text { Number of people the } \\
\text { respondent contacts per day }\end{array}$} & $0.273 * *$ & 1.313 & -0.116 & 0.890 & $0.225 *$ & 1.253 \\
\hline & $(0.079)$ & $(0.056)$ & $(0.091)$ & $(-0.029)$ & $(0.093)$ & $(0.056)$ \\
\hline & -0.032 & 0.968 & 0.033 & 1.033 & 0.089 & 1.093 \\
\hline & $(0.075)$ & $(-0.007)$ & $(0.061)$ & $(0.008)$ & $(0.056)$ & $(0.022)$ \\
\hline \multirow[t]{2}{*}{ Trust in people in general } & 0.136 & 1.145 & $0.447 * *$ & 1.563 & 0.173 & 1.189 \\
\hline & $(0.190)$ & $(0.028)$ & $(0.163)$ & $(0.111)$ & $(0.139)$ & $(0.043)$ \\
\hline \multirow[t]{2}{*}{ Trust in relatives } & -0.150 & 0.860 & 0.031 & 1.032 & 0.007 & 1.007 \\
\hline & $(0.139)$ & $(-0.031)$ & $(0.123)$ & $(0.008)$ & $(0.110)$ & $(0.002)$ \\
\hline \multirow{4}{*}{$\begin{array}{l}\text { Trust in people the respondent } \\
\text { interacts with } \\
\text { Constant }\end{array}$} & 0.253 & 1.288 & 0.120 & 1.128 & -0.017 & 0.984 \\
\hline & $(0.155)$ & $(0.052)$ & $(0.117)$ & $(0.030)$ & $(0.116)$ & $(-0.004)$ \\
\hline & 0.385 & & -0.493 & & -0.331 & \\
\hline & $(0.409)$ & & $(0.312)$ & & $(0.295)$ & \\
\hline $\mathrm{N}$ & \multicolumn{2}{|c|}{673} & \multicolumn{2}{|c|}{782} & \multicolumn{2}{|c|}{1018} \\
\hline Likelihood ratio test & \multicolumn{2}{|c|}{$17.55 * *$} & \multicolumn{2}{|c|}{$13.42 *$} & \multicolumn{2}{|c|}{$12.80 *$} \\
\hline Pseudo $R^{2}$ & \multicolumn{2}{|c|}{0.02} & \multicolumn{2}{|c|}{0.01} & \multicolumn{2}{|c|}{0.01} \\
\hline$-2 \times$ Log-Likelihood & \multicolumn{2}{|c|}{800.32} & \multicolumn{2}{|c|}{1070.41} & \multicolumn{2}{|c|}{1398.17} \\
\hline
\end{tabular}

Note: 1. Coef. = Regression Coefficient; S.E. = Standard Error; O.R. = Odds Ratio; M.E. = Maximum effect in terms of probability change.

2. ** is significant at $p<0.01 ; *$ is significant at $p<0.05$.

The final step of my analysis is to include control variables related to support for democracy in the model to see whether the results of simple model are robust. First of all, the number of groups in which people participate still has a significant effect on public support for democracy in Japan and there is also a significant causal relationship between trust in people in general and support for democracy in South Korea. However, the effects of both of them on support for democracy in Japan and South Korea are decreased after adding control variables to the model. On the other hand, the number of groups in which people participate becomes statistically insignificant and the number of other people with whom people interact achieves marginally statistical significance $(p=0.053)$ in Taiwan, which suggest that social networks simply have a marginal influence on public support for democracy in Taiwan.

Second, this study finds that trust in political institutions, democratic values, education, and age have significant effects on public support for democracy in all three countries. In comparison with interpersonal trust, trust in political institutions plays a more important role in affecting public support for democracy in Japan, South Korea, and Taiwan. That is, people who have higher levels of trust in political institutions are more likely to support democracy. This result is not surprising, because the operation of democracy depends on the quality and maturity of political institutions. Therefore, if people exhibit high levels of trust in political institutions, which implies that they are satisfied with the performance of political institutions and believe that political institutions work in the right way, they will be more likely to support democracy. Specifically, Table 8 shows that if people have the highest level of trust in political institutions, the probability of their support for democracy will increase by 17.6 percent in Japan, 11.0 percent in South Korea, and 12.2 percent in Taiwan. Besides, it is reasonable to expect the close relationship between democratic values and support for democracy. This study finds that people with higher levels of democratic values are more likely to favor democracy. Specifically, if people have highest level of democratic values, the probability of their support for democracy will increase by 23.8 percent in Japan, 13.5 percent in South Korea, and 17.1 percent in Taiwan.

This study also finds that there is a significant relationship between education and support for democracy. That is, people with higher levels of education are more likely to support democracy than those with lower levels of education. This result confirms Lipset's argument that education plays an important role in a democracy. As Lipset said, the higher one's education, the more likely one is to believe in democratic values and support democratic practices (Lispet, 1960). Finally, age is also significantly associated with support for democracy. That is, the older people are, the more likely they are to favor democracy. This may be because older people experienced the period of authoritarian dominance so that they know the merits of democracy and do not want authoritarian regime to resurge. As a result, older people in these three East Asian countries have higher levels of support for democracy than young people. 
To sum up, this study lends some support to the relationships between social networks, interpersonal trust and public support for democracy in Japan, South Korea, and Taiwan. In other words, social networks, rather than interpersonal trust, exert significant positive effects on public support for democracy in Japan and Taiwan. On the contrary, it is interpersonal trust to affect public support for democracy in South Korea. Nonetheless, it should also be noted that trust in political institutions, democratic values, and education far outweigh social networks and interpersonal trust to impact public support for democracy in these East Asian countries. As a result, the effects of social networks and interpersonal trust on public support for democracy should not be overemphasized.

Table 8. Binary Logistic Analysis of Support for Democracy - Full Model

\begin{tabular}{|c|c|c|c|c|c|c|}
\hline & \multicolumn{2}{|c|}{ Japan } & \multicolumn{2}{|c|}{ South Korea } & \multicolumn{2}{|c|}{ Taiwan } \\
\hline & $\begin{array}{l}\text { Coef. } \\
\text { (S.E.) }\end{array}$ & $\begin{array}{c}\text { O.R. } \\
\text { (M.E.) }\end{array}$ & $\begin{array}{l}\text { Coef. } \\
\text { (S.E.) }\end{array}$ & $\begin{array}{c}\text { O.R. } \\
\text { (M.E.) }\end{array}$ & $\begin{array}{l}\text { Coef. } \\
\text { (S.E.) }\end{array}$ & $\begin{array}{c}\text { O.R. } \\
\text { (M.E.) }\end{array}$ \\
\hline Number of groups the respondent participates in & $\begin{array}{c}0.167 * \\
(0.085)\end{array}$ & $\begin{array}{c}1.182 \\
(0.033)\end{array}$ & $\begin{array}{r}-0.118 \\
(0.094)\end{array}$ & $\begin{array}{c}0.889 \\
(-0.029)\end{array}$ & $\begin{array}{r}0.141 \\
(0.098)\end{array}$ & $\begin{array}{c}1.152 \\
(0.035)\end{array}$ \\
\hline Number of people the respondent contacts per day & $\begin{array}{r}-0.011 \\
(0.083)\end{array}$ & $\begin{array}{c}0.989 \\
(-0.002)\end{array}$ & $\begin{array}{r}0.053 \\
(0.063)\end{array}$ & $\begin{array}{c}1.054 \\
(0.013)\end{array}$ & $\begin{array}{l}0.112 \$ \\
(0.058)\end{array}$ & $\begin{array}{c}1.119 \\
(0.028)\end{array}$ \\
\hline Trust in people in general & $\begin{array}{r}0.038 \\
(0.200)\end{array}$ & $\begin{array}{c}1.039 \\
(0.007)\end{array}$ & $\begin{array}{l}0.353 * \\
(0.168)\end{array}$ & $\begin{array}{c}1.424 \\
(0.088)\end{array}$ & $\begin{array}{r}0.068 \\
(0.143)\end{array}$ & $\begin{array}{c}1.070 \\
(0.017)\end{array}$ \\
\hline Trust in relatives & $\begin{array}{r}-0.231 \\
(0.147)\end{array}$ & $\begin{array}{c}0.793 \\
(-0.046)\end{array}$ & $\begin{array}{r}-0.015 \\
(0.126)\end{array}$ & $\begin{array}{c}0.985 \\
(-0.004)\end{array}$ & $\begin{array}{r}-0.090 \\
(0.115)\end{array}$ & $\begin{array}{c}0.914 \\
(-0.023)\end{array}$ \\
\hline Trust in people the respondent interacts with & $\begin{array}{r}0.213 \\
(0.161)\end{array}$ & $\begin{array}{c}1.237 \\
(0.042)\end{array}$ & $\begin{array}{r}0.137 \\
(0.120)\end{array}$ & $\begin{array}{c}1.147 \\
(0.034)\end{array}$ & $\begin{array}{r}-0.062 \\
(0.120)\end{array}$ & $\begin{array}{c}0.940 \\
(-0.016)\end{array}$ \\
\hline Trust in political institutions & $\begin{array}{l}0.894 * * * \\
(0.231)\end{array}$ & $\begin{array}{c}2.446 \\
(0.176)\end{array}$ & $\begin{array}{l}0.441 * * \\
(0.166)\end{array}$ & $\begin{array}{c}1.554 \\
(0.110)\end{array}$ & $\begin{array}{l}0.489 * * \\
(0.152)\end{array}$ & $\begin{array}{c}1.630 \\
(0.122)\end{array}$ \\
\hline Democratic values & $\begin{array}{l}1.207 * * * \\
(0.241)\end{array}$ & $\begin{array}{c}3.343 \\
(0.238)\end{array}$ & $\begin{array}{l}0.541 * \\
(0.227)\end{array}$ & $\begin{array}{c}1.718 \\
(0.135)\end{array}$ & $\begin{array}{l}0.684 * * \\
(0.229)\end{array}$ & $\begin{array}{c}1.982 \\
(0.171)\end{array}$ \\
\hline College and above degree & $\begin{array}{l}0.546 * * \\
(0.195)\end{array}$ & $\begin{array}{c}1.726 \\
(0.108)\end{array}$ & $\begin{array}{l}0.469 * * \\
(0.171)\end{array}$ & $\begin{array}{c}1.598 \\
(0.117)\end{array}$ & $\begin{array}{l}0.661 * * * \\
(0.160)\end{array}$ & $\begin{array}{c}1.937 \\
(0.163)\end{array}$ \\
\hline Female & $\begin{array}{r}0.278 \\
(0.188)\end{array}$ & $\begin{array}{c}1.320 \\
(0.054)\end{array}$ & $\begin{array}{r}0.236 \\
(0.154)\end{array}$ & $\begin{array}{c}1.266 \\
(0.059)\end{array}$ & $\begin{array}{r}-0.134 \\
(0.132)\end{array}$ & $\begin{array}{c}0.875 \\
(-0.033)\end{array}$ \\
\hline Age & $\begin{array}{c}0.013 * \\
(0.006)\end{array}$ & $\begin{array}{c}1.013 \\
(0.003)\end{array}$ & $\begin{array}{l}0.014 * \\
(0.006)\end{array}$ & $\begin{array}{c}1.014 \\
(0.004)\end{array}$ & $\begin{array}{l}0.018 * * * \\
(0.005)\end{array}$ & $\begin{array}{c}1.019 \\
(0.005)\end{array}$ \\
\hline Constant & $\begin{array}{l}-3.526 * * * \\
(0.769)\end{array}$ & & $\begin{array}{l}-2.728 * * * \\
(0.640)\end{array}$ & & $\begin{array}{l}-2.692 * * * \\
(0.580)\end{array}$ & \\
\hline$\overline{\mathrm{N}}$ & 673 & & 782 & & 1018 & \\
\hline Likelihood ratio test & 76.0 & $4 * * *$ & 36. & $5 * * *$ & 59.1 & $6 * * *$ \\
\hline Pseudo $R^{2}$ & 0.09 & & 0.0 & & 0.04 & \\
\hline$-2 \times$ Log-Likelihood & 741.8 & & 1047 & & 1351.8 & \\
\hline
\end{tabular}

Note: 1. Coef. $=$ Regression Coefficient; S.E. = Standard Error; O.R. = Odds Ratio; M.E. = Maximum effect in terms of probability change.

2. *** is significant at $p<0.001 ; * *$ is significant at $p<0.01 ; *$ is significant at $p<0.05 ; \$$ is significant at $p<$ 0.10 .

\section{Conclusions}

Conventional wisdom asserts that democracies require a strong civil society and high levels of interpersonal trust. Gibson (2001) challenged this conventional wisdom and found that in Russia those embedded in extensive social networks are more likely to support key democratic institutions and processes; however, for most Russians, interpersonal trust is certainly not a prerequisite to support for democratic institutions and processes. This study follows the framework of Gibson's study, but switches attention to three East Asian democracies - Japan, South Korea, and Taiwan. The results of this study find that similar to Russia, social networks have significant positive effects on public support for democracy and there is no relationship between interpersonal trust and public support for democracy in Japan and Taiwan. However, in South Korea, it is interpersonal trust, rather than social networks, to impact public support for democracy. Although both social networks and interpersonal trust are regarded as prerequisites to support democracy, this study finds that either one of them has a significant effect on public support for democracy, that is, social networks for Japan and Taiwan, and interpersonal trust for South Korea. As a result, it is known that in stable democracies like Japan, South Korea, and Taiwan, public support for democracy does not necessarily depend on social networks and interpersonal trust simultaneously, although both of them are viewed as two important elements of civil society. Besides, it must be kept in 
mind that this study does not deny the close relationship between civil society and democracy. Social networks and interpersonal trust are only two indicators of civil society and they cannot completely catch the concept of civil society. Furthermore, because my measurement of social networks and interpersonal trust are different from Gibson's measurement, I would not overemphasize the differences between my findings and Gibson's results.

On the other hand, Gibson reminded us that careful attention must be given to the various forms of trust. This study finds that trust in political institutions plays an important role in affecting public support for democracy and its effect far outweighs social networks and interpersonal trust in these three East Asian countries. This finding indirectly confirms the relationship between democracy and political institutions. Institutionalization is a prerequisite to the operation of democracy, and thus, under well-working political institutions, people will be more confident in democracy and support its existence. In my opinion, public support for democracy largely depends on whether political institutions work to satisfy people's expectations. Nonetheless, it does not mean that I deny the importance of civil society in democracy. As Berman said (1997), both civil society and political institutions are needed to be taken into consideration when we explain what causes democratization as well as what makes democracies vibrant and successful over the long term.

Finally, Gibson thought that the relationship between social networks and democracy is based upon the assumption that social networks can facilitate social learning about the art of democratic governance. This study also follows such assumption, but I have to acknowledge that Gibson's study and this study do not provide any empirical evidence to confirm this assumption. Therefore, although this study finds that those with extensive social networks are more likely to support democracy, future studies are needed to explain the causal mechanism between social networks and support for democracy.

\section{References}

Albritton, R., \& Bureekul, T. (2002). Civil society and the consolidation of democracy in Thailand. Asian Barometer Working Paper Series, 4, 1-30. http://www.asianbarometer.org/newenglish/publications/workingpapers/no.4.pdf.

Anderson, C. J., \& Guillory, C. A. (1997). Political institutions and satisfaction with democracy: a cross-national analysis of consensus and majoritarian systems. American Political Science Review, 91(1), 66-81.

Berman, S. (1997). Civil society and political institutionalization. American Behavioral Scientists, 40(5), 562-574. http://dx.doi.org/10.1177/0002764297040005003

Bunbongkarn, S. (2004). The role of civil society in democratic consolidation in Asia. In Y. Sato (Ed.), Growth and governance in Asia, Honolulu, HI: Asia-Pacific Center for Security Studies, 137-144.

Chu, Y., Bratton, M., Lagos, M., Shastri, S., \& Tessler, M. (2008). Public opinion and democratic legitimacy. Journal of Democracy, 19(2), 74-87.

Gibson, J. L. (2001). Social networks, civil social, and the prospects for consolidating Russia's democratic transition. American Journal of Political Science, 45(1), 51-69. http://dx.doi.org/10.2307/2669359

Huntington, S. P. (1968). Political order in changing societies. New Haven, CT: Yale University Press.

Inglehart, R., \& Welzel, C. (2005). Modernization, cultural change, and democracy: The human development sequence. New York, NY: Cambridge University Press.

La Due Lake, R., \& Huckfeldt, R. (1998). Social capital, social networks, and political participation. Political Psychology, 19(3), 567-584. http://dx.doi.org/10.1111/0162-895X.00118

Linz, J. J., \& Stepan, A. (2001). Toward Consolidated Democracies. In L. Diamond, \& M. F. Plattner (Eds.), The global divergence of democracies, Baltimore, MD: Johns Hopkins University Press, 93-112.

Lipset, S. M. (1960). Political man: The social bases of politics. Garden City, NY: Doubleday.

Mishler, W., \& Rose, R. (2005). What are the political consequence of trust? A test of cultural and institutional theories in Russia. Comparative Political Studies, 38(9), 1050-1078. http://dx.doi.org/10.1177/0010414005278419

Newton, K. (2001). Trust, social capital, civil society, and democracy. International Political Science Review, 22(2), 201-214. http://dx.doi.org/10.1177/0192512101222004

O’Donnell, G. (1998). Horizontal accountability in new democracies. Journal of Democracy, 9(3), 112-126.

Putnam, R. D., Leonardi, R., \& Nanetti, R. Y. (1993). Making democracy work: Civic traditions in modern Italy. Princeton, NJ: Princeton University Press.

Putnam, R. D. (1995). Bowling alone: America's declining social capital. Journal of Democracy, 6(1), 65-78.

Schmitter, P. (1997). Civil society East and West. In Diamond, L., Plattner, M. F., Chu, Y., \& Tien, H. (Eds.), Consolidating the third wave democracies: Themes and perspectives, Baltimore, MD: Johns Hopkins University 
Press, 239-262.

Zmerli, S., \& Newton, K. (2008). Social trust and attitudes toward democracy. Public Opinion Quarterly, 72(4), 706-724. http://dx.doi.org/10.1093/poq/nfn054

Appendix. Questions in the Asian Barometer Survey

\begin{tabular}{|c|c|}
\hline Variables & Question wording \\
\hline Support for democracy & $\begin{array}{l}\text { Which of the following statements comes closest to your view: (1) Democracy is always } \\
\text { preferable to any other kind of government; (2) Under some circumstances, an authoritarian } \\
\text { government can be preferable to a democratic one; (3) For people like me, it does not matter } \\
\text { whether we have a democratic or a nondemocratic regime. }\end{array}$ \\
\hline $\begin{array}{l}\text { Number of groups the } \\
\text { respondent participates in }\end{array}$ & $\begin{array}{l}\text { Are you a member of any organization or formal groups? If YES: Please tell me the three (3) } \\
\text { most important organizations or formal groups you belong to. }\end{array}$ \\
\hline $\begin{array}{l}\text { Number of people the } \\
\text { respondent contacts per day }\end{array}$ & $\begin{array}{l}\text { On average, about how many people do you have contact with in a typical week day? We are } \\
\text { interested in contact on a one-on-one basis, including everyone with whom you chat, talk, or } \\
\text { discuss matters. This can be face to face, by telephone, by mail, or on the internet. Please } \\
\text { include only people you know. }\end{array}$ \\
\hline Trust in people in general & $\begin{array}{l}\text { General speaking, would you say that "Most people can be trusted" or "that you must be } \\
\text { very careful in dealing with people"? }\end{array}$ \\
\hline Trust in relatives & How much trust do you have in each of the following types of people? Your relatives. \\
\hline $\begin{array}{l}\text { Trust in people the respondent } \\
\text { interacts with }\end{array}$ & $\begin{array}{l}\text { How much trust do you have in each of the following types of people? Other people you } \\
\text { interact with. }\end{array}$ \\
\hline Trust in political institutions & $\begin{array}{l}\text { I am going to name a number of institutions. For each one, please tell me how much trust do } \\
\text { you have in them? Is It a great deal of trust, quite a lot of trust, not very much trust not very } \\
\text { much trust, or none at all? } \\
\text { 1. The Presidency (for presidential system) or Prime Minister (for parliamentary system). } \\
\text { 2. The Courts. } \\
\text { 3. The national government [in capital city]. } \\
\text { 4. Political parties [not any specific party]. } \\
\text { 5. Parliament. } \\
\text { 6. Civil service. } \\
\text { 7. The military (or armed forces). } \\
\text { 8. The police. } \\
\text { 9. Local government. }\end{array}$ \\
\hline
\end{tabular}

For each statement, would you say you strongly agree, somewhat agree, somewhat disagree, or strongly disagree?

1. People with little or no education should have as much say in politics as highly-educated people.

2. Government leaders are like the head of a family; we should all follow their decisions

3. The government should decide whether certain ideas should be allowed to be discussed in society.

Democratic values 4. Harmony of the community will be disrupted if people organize lots of groups.

5. When the country is facing a difficult situation, it is ok for the government to disregard the law in order to deal with the situation.

6. If the government is constantly checked [i.e. monitored and supervised] by the legislature, it cannot possibly accomplish great things.

7. If we have political leaders who are morally upright, we can let them decide everything.

8. If people have too many different ways of thinking, society will be chaotic.

When judges decide important cases, they should accept the view of the executive branch.

\begin{tabular}{ll}
\hline Education & Respondents' educational level \\
\hline Gender & Respondents' gender \\
\hline Age & Respondents' age \\
\hline
\end{tabular}

\section{(cc) $\mathrm{EY}$}

This work is licensed under a Creative Commons Attribution 3.0 License. 